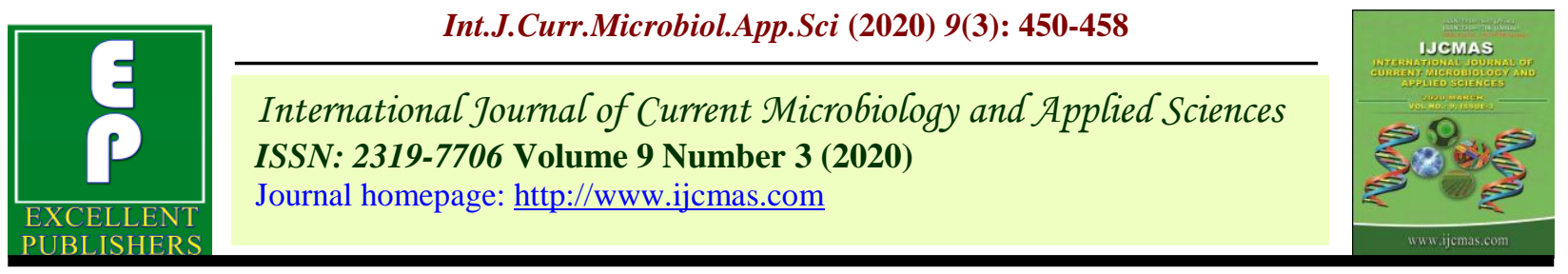

Original Research Article

https://doi.org/10.20546/ijcmas.2020.903.052

\title{
Efficacy of Integrated Management of Web Blight of Mungbean in Kymore Plateu and Satpura Hills Agroclimatic Zone of Madhya Pradesh, India
}

\author{
Jai Singh $^{1}$, Ashish Kumar ${ }^{2 *}$ and S. R. Sharma ${ }^{3}$ \\ ${ }^{1} J N K V V$, Krishi Vigyan Kendra, Singrauli, M.P. - 486 88, India \\ ${ }^{2}$ Plant Pathology, JNKVV, College of Agriculture, Jabalpur, M.P. - 482 004, India \\ ${ }^{3} J N K V V$, Krishi Vigyan Kendra, Narsinghpur, M.P.- 487 001, India \\ *Corresponding author
}

\section{A B S T R A C T}

Keywords

Mungbean,

Integrated disease

management, Web

blight, disease

incidence

Article Info

Accepted:

05 February 2020

Available Online:

10 March 2020
In order to assess the efficacy of four different integrated management modules including farmers practice for web blight disease of green gram, a three year on farm trials were conducted on 46 farmer's fields of Sarethi, Chhavari, Mankesher and Barmani Villages in Sidhi District of Madhya Pradesh during 2016-2019. The average web blight incidence ranged from 15.6 to $51.25 \%$ in different surveyed mungbean producing areas. The experimental findings revealed that all three management modules were found superior over farmers practice. The modules $\mathrm{T}_{4}$ having seed treatment with Carboxin @ $2 \mathrm{~g} / \mathrm{kg}$ seed + Seed inoculation of Rhizobium @20 g/ kg Seed + Soil treatment with Trichoderma viridi @ $5 \mathrm{~kg}$ incubated in $50 \mathrm{~kg}$ vermicompost for $72 \mathrm{hrs}$. + Foliar spray of $10 \%$ kranj leaf extract at 30 DAS and Propiconazole-25SC @ 0.1\% at 45 DAS at early onset of disease was found most effective in reducing and web blight disease incidence $(80.08 \%)$ and increasing the yield (44.32\%) and benefit cost ratio (1.69). This was followed by Seed treatment with Carboxin @ $2 \mathrm{~g}+$ Seed inoculation of Trichoderma viridi @ $5 \mathrm{~g} / \mathrm{kg}$ seed + Rhizobium and PSB @ $20 \mathrm{~g} / \mathrm{kg}$ seed + foliar spray of $10 \%$ Kranj leaf extract at 30 DAS. It can be concluded that module $\mathrm{T}_{4}$ may be considered for improved sustainable management of web blight in mungbean.

\section{Introduction}

Mungbean (Vigna radiata (L.) Wilczek) commonly known as green gram or golden gram is an important pulse crop. Mungbean seeds are rich in proteins $(\sim 24 \%$ easily digestible protein), fiber, antioxidants, and phytonutrients (Itoh et al., 2006). Mungbean is consumed as whole seed or split cooking, flour, or as sprouts, thus, forms an important source of dietary protein. Mungbean sprouts contain high amounts of thiamine, niacin, and ascorbic acid. India is the largest producer of mungbean, however, it is cultivated throughout Asia including Pakistan, Bangladesh, Sri Lanka, Thailand, Cambodia, 
Vietnam, Indonesia, Malaysia, South China, Africa, Australia, United State of America and West Indies. In India it is grown in almost all parts of the country during summer and rainy season. Mungbean is the third most important pulse crop of India covering an area of approximately 4.305 million hectares and production of 2.07 million tons of grain with productivity of $481 \mathrm{~kg} / \mathrm{ha}$ (Anonymous, 2017). Yield potential of mungbean is in the range of 2.5-3.0 t/ha, however, the average productivity of mungbean is staggering low due to several abiotic and biotic constraints, poor crop management practices and nonavailability of quality seeds of improved varieties to farmers (Chauhan et al., 2010; Pratap et al., 2019).

Among the biotic factors, Web blight is not only one of the major constraints in the production of mungbean alone but for many other pulses in warm humid tropic zones of the world also. In Mungbean, Rhizoctonia blight was firstly reported from Philippines in 1924 (Nacien, et al., 1924). In India, first report of Web blight occurrence in mungbean was given by Dwivedi and Saksena in 1974 from Kanpur, Uttar Pradesh and subsequently it has been reported from Assam (Saikia, 1976), Punjab (Bains et al., 1988), Madhya Pradesh (Tiwari and Khare, 1998), Bihar, Rajsthan, Haryana and Himanchal Pradesh (Anonymous, 2014).

In 1976 Saikia gave an account of the incidence and etiology of blight of Phaseolus aureus (Vigna radiata) resulting into 17-90 per cent incidence. The disease has been observed to reduce 33 to 40 per cent grain yield and 28.6 per cent in 1000 grain weight at different level of disease severity and in different variety of mungbean (Gupta et al., 2010 and Singh et al., 2012). Since then, the web blight of mungbean has become one of the most serious problems of this crop in Northern India causing extensive damage to mungbean. In order to reduce the web blight severity in Mungbean, a number of fungicides have been tried and among them Propiconazole (Akhtar et al., 2014) and Carbendazim (Jhamaria and Sharma, 2002) have been found highly effective in controlling the disease.

Presently, farmers are extensively using several fungicides either singly or in combination to protect crop from any type of damage caused by Web blight disease, however, they have been failed to minimize the losses. The often indiscriminate use of huge amount of fungicides has resulted in phyto-toxicity, destruction of earthworms, and other health hazards. An attempt was, therefore, made to evaluate integrated web blight management modules as a rational approach to develop effective and ecofriendly Integrated Disease Management Modules (IDMs) for sustainable production of mungbean.

\section{Materials and Methods}

\section{Field Survey}

During the year 2015-16, surveys were conducted for the presence of web blight disease of mungbean in 16 different villages viz., Upani, Sonversha, Bhaisarha, Jhalwar, Chorgarhi, Chauwahi, Tikari, Tamsar, Tenduha no.-1, Barhai, Sarethi, Gopalpur, Madhuri, Gajaraha, Mamder and Mata with varying latitudes and longitudes (Table 2) in five different field were chosen from each villages of four different blocks of Sidhi District in Madhya Pradesh during the months of July- August In the each visited field three plot of size $1 \times 1$ meter were selected to observe overall disease incidence on visual symptoms. Data were recorded on disease incidence (\%) by counting total number of plant as well as diseased plant. Per cent disease incidence was calculated by following formula given by (Nene, 1972). 
Disease Incidence $(\%)=\quad$ (No. of diseased plants / Total no. of assessed plants) x 100

\section{Integrated disease management}

A field experiment was conducted during Kharif season of 2016-17, 2017-18 and 201819 at 46 farmer's fields of Sarethi, Bermani, Chhavari and Mankesher villages of Sidhi district by Krishi Vigyan Kendra, Sidhi (MP) to find out efficacy of different integrated disease management modules against web blight disease of mungbean under the On Farm Trial (OFT) activity of KVK. The trials were laid out in Randomized block design having four treatments including control (farmers practice) maintaining 5 replications (Table 1). The experimental field was prepared by ploughing thrice with cultivator followed by planking for fine tilt and smooth surface.

Recommended dose of FYM (1 t/ha) was mixed in soil 30 days before sowing and recommended dose of fertilizers (20:40:20 kg NPK/ha) was applied at the time of sowing. The seed variety HUM- 12 was grown at $45 \mathrm{x}$ $15 \mathrm{~cm}$ spacing. Standard agronomical practices were followed to grow the crop. Incidence of the disease was recorded seven days after imposing the treatment by taking counts of twenty randomly selected and tagged plants leaving the borders. Percent disease incidence and reduction in disease incidence were calculated by following formulae as given above by Nene (1972).

Reduction in disease incidence (\%)

$=\{($ Disease incidence in untreated plotsdisease incidence in treated plot) / Disease incidence in untreated plots $\mathrm{x} 100$

\section{Estimation of Benefit-Cost Ratio}

Grain yield of each plot was taken from whole population separately and yield of each module was calculated by cumulating the successive plucking from respective field and computing to kilogram per hectare. The data were tabulated, pooled and ranked on the basis of their yield performance. The benefitcost ratio (BCR) of different modules was calculated by estimating different cost of cultivation and return from yield after converting them to one hectare land. Average market price of mungbean was rupees 52.0 per $\mathrm{kg}$ during experimental period. Benefitcost ratio was calculated by using following formula:

$\mathrm{BCR}=$ Grass income $/$ total cost of cultivation

The field data was analyzed in Randomized Block design by $F$ test for significance and critical difference of values were calculated at 5 per cent probability level.

\section{Results and Discussion}

\section{Field survey}

In total 16 locations were surveyed from 05 blocks of Madhya Pradesh. It was observed that surveyed areas were predominately occupied with four Mungbean varieties namely HUM-1,HUM-6,Pusa Vishal K-851 and TM-37. The average web blight incidence ranged from 15.6 to $51.25 \%$ in different surveyed areas of mungbean production. However, the disease incidence significantly varied not only at different locations but also among different varieties used by respective farmer. Maximum average incidence of web blight of mungbean was recorded in different locations of Sidhi block. Among different locations of Sidhi, highest average incidence of $51.25 \%$ was recorded in Upani location. Different locations of Rampur Naikin block showed lesser incidence in surveyed area and minimum incidence of $15.6 \%$ was recorded for web blight of mungbean from Mamder 
location. Among the four varieties, it was observed that K-851 was showing more average incidence of web blight in comparision to TM-37 in different locations of Raipur Naikin. Detailed data for 16 different locations of five blocks of Madhya Pradesh for incidence of web blight of mungbean has been presented in table 2 along with GPS locations of surveyed fields.

The variation in the web blight incidence in year at different place could be attributed to seed and soil born nature of $R$. solani. Singh et al., 2003 reported that web blight incidence varied from 1.0 to 69 percent with an average of 12.7 in Eastern Uttar Pradesh. In another study by Saikia, 1976 a high disease incidence (85-90\%) coupled with $25-30 \%$ plant mortality had been observed earlier due to $R$. solani.

\section{Integrated disease management}

The impact of four different IDM modules on the severity of web blight disease in mungbean was recorded. The web blight disease incidence varied from 8.80 to 51.5 per cent depending on IDMs during different years. During all the three years minimum disease incidence was recorded in treatment $\mathrm{T}_{4}$ (Seed treatment with Carboxin @ $2 \mathrm{~g} / \mathrm{kg}$ seed + Seed inoculation of Rhizobium @ 20 g/kg Seed + Soil treatment with Trichoderma viridi @ $5 \mathrm{~kg}$ incubated in $50 \mathrm{~kg}$ vermicompost for 72 hrs. + Foliar spray of 10 $\%$ kranj leaf extract at 30 DAS and Propiconazole-25SC @ 0.1\% at 45 DAS). Lowest average web blight disease incidence of $9.33 \%$ was recorded in the treatment $\mathrm{T}_{4}$. This was followed by treatment $\mathrm{T}_{3}$ (Seed treatment with Carboxin @ $2 \mathrm{~g}+$ Seed inoculation of Trichoderma viridi@ $5 \mathrm{~g} / \mathrm{kg}$ seed + Rhizobium and PSB @ 20 g/kg seed + foliar spray of $10 \%$ Kranj leaf extract at 30 DAS) where $16.39 \%$ disease incidence was recorded. Reduction in disease incidence over check $\left(T_{1}\right)$ was calculated and it was observed that treatment $\mathrm{T}_{4}$ maximum inhibited the disease and $80.08 \%$ disease control was recorded over control. The highest disease incidence for all the three years was recorded in $\mathrm{T}_{1}$ (Control) with average disease incidence of $46.84 \%$. The detailed data for disease incidence during different years in all the four treatments are given in table 3 .

Further yield and number of pods per plant was recorded in different treatments and it was observed that maximum yield and number of pods per plant were recorded in treatment $\mathrm{T}_{4}$ during all the three years. The maximum average yield and average number of pods per plant of respectively $579.33 \mathrm{~kg} / \mathrm{ha}$ and 22.13 was recorded in the treatment $\mathrm{T}_{4}$. This was followed by treatment $T_{3}$ where respectively $501.03 \mathrm{~kg} / \mathrm{ha}$ and 19.73 average yield and average number of pods per plant were recorded. However, minimum average yield and average number of pods per plant of respectively $401.42 \mathrm{~kg} / \mathrm{ha}$ and 15.2 was recorded in the treatment $\mathrm{T}_{1}$. Treatment $\mathrm{T} 4$ was having respectively $44.32 \%$ and $45.59 \%$ increase in yield and pods per plant over control $\mathrm{T}_{1}$. The detailed data for all the IDM modules for yield and pods per plant in mungbean are given in table 4 .

Use of different bio-control agents especially Trichoderma is a pragmatic approach for plant disease management in various crops and also can be utilized in other purposes like biofertilizers, in bio-remediation, plant growth promoting agents etc. (Kumar et al., 2009; Srivastava et al., 2009; Kumar et al., 2014; Kumar et al., 2015 and Jain et al., 2016). Seed treatment and soil application of $T$. viride effectively reduced growth of $R$. solani and also promoted plant growth in urd and mungbean (Dubey and Patel, 2002; Dubey et al., 2011). 
Table.1 Details of different Integrated Disease Management Modules (IDMs) in mungbean

\begin{tabular}{|l|l|}
\hline Treatment & Details \\
\hline $\mathbf{T}_{\mathbf{1}}$ & Control \\
\hline $\mathbf{T}_{\mathbf{2}}$ & $\begin{array}{l}\text { Seed treatment with Carboxin @ } \\
\text { Trichoderma viridi @ 5 } \mathrm{g} / \mathrm{kg} \text { seed }\end{array}$ \\
\hline $\mathbf{T}_{\mathbf{3}}$ & $\begin{array}{l}\text { Seed treatment with Carboxin @ } 2 \mathrm{~g}+\text { Seed inoculation of Trichoderma } \\
\text { viridi @ 5 } / \mathrm{kg} \text { seed }+ \text { Rhizobium and PSB @ 20 g/kg seed + foliar spray } \\
\text { of } 10 \% \text { Kranj leaf extract at 30 DAS }\end{array}$ \\
\hline $\mathbf{T}_{\mathbf{4}}$ & $\begin{array}{l}\text { Seed treatment with Carboxin @ } 2 \mathrm{~g} / \mathrm{kg} \text { seed + Seed inoculation of } \\
\text { Rhizobium @ 20 } / \mathrm{kg} \text { Seed + Soil treatment with Trichoderma viridi @ 5 } \\
\text { kg incubated in 50 kg vermicompost for } 72 \mathrm{hrs}++ \text { Foliar spray of } 10 \% \\
\text { kranj leaf extract at 30 DAS and Propiconazole-25SC @ 0.1\% at 45 DAS }\end{array}$ \\
\hline
\end{tabular}

Table.2 Incidence of Web blight of mungbean in different blocks of Sidhi district (Madhya Pradesh)

\begin{tabular}{|c|c|c|c|c|c|c|}
\hline \multirow[t]{2}{*}{ Locations } & \multirow[t]{2}{*}{ Block } & \multirow[t]{2}{*}{ Variety } & \multicolumn{2}{|c|}{ GPS Location } & \multicolumn{2}{|c|}{$\begin{array}{c}\text { Disease Incidence } \\
(\%)\end{array}$} \\
\hline & & & Latitude & Longitude & Range & Average \\
\hline Upani & Sidhi & K-851 & $24^{0} 22^{\prime} 58.6^{\prime \prime}$ & $81^{0} 56^{\prime} 25.9^{\prime \prime}$ & $21-69$ & 51.25 \\
\hline Sonversha & Sidhi & HUM-6 & $24^{0} 23^{\prime} 57.5^{\prime \prime}$ & $81^{0} 47^{\prime} 36.0^{\prime \prime}$ & $26-52$ & 42.60 \\
\hline Bhaisharha & Rampur Naikin & K-851 & $24^{0} 17^{\prime} 23.0^{\prime \prime}$ & $81^{0} 21^{\prime} 46.2^{\prime \prime}$ & $21-43$ & 39.40 \\
\hline Jhalwar & Rampur Naikin & TM-37 & $24^{0} 23^{\prime} 34.9^{\prime \prime}$ & $81^{0} 34^{\prime} 19.9 "$ & $08-29$ & 18.00 \\
\hline Chorgahi & Rampur Naikin & PusaVishal & $24^{0} 18^{\prime} 52.9^{\prime \prime}$ & $81^{0} 24^{\prime} 40.2^{\prime \prime}$ & $18-34$ & 24.50 \\
\hline Chuwahi & Majhauli & $\mathrm{K}-851$ & $24^{0} 08^{\prime} 29.5^{\prime \prime}$ & $81^{0} 36^{\prime} 6.28^{\prime \prime}$ & $12-46$ & 39.00 \\
\hline Tikari & Majhauli & HUM-1 & $24^{0} 10^{\prime} 6.3^{\prime \prime}$ & $81^{0} 51^{\prime} 35.8 ”$ & $00-49$ & 35.00 \\
\hline Tamsar & Kushmi & TM-37 & $24^{0} 12^{\prime} 1.3^{\prime \prime}$ & $81^{0} 50^{\prime} 49.5^{\prime \prime}$ & $13-42$ & 37.50 \\
\hline Tenduha No.- & Sihawal & $\mathrm{K}-851$ & $24^{0} 24^{\prime} 51.2^{\prime \prime}$ & $81^{\circ} 01^{\prime} 44.8^{\prime \prime}$ & $11-55$ & 41.70 \\
\hline Barhai & Sidhi & HUM-1 & $24^{0} 12^{\prime} 46.2^{\prime \prime}$ & $81^{0} 45^{\prime} 48.20^{\prime \prime}$ & $05-58$ & 49.00 \\
\hline Sarethi & Sidhi & HUM-1 & $24^{0} 15^{\prime} 17.7^{\prime}$ & $81^{0} 44^{\prime} 8.3^{\prime \prime}$ & $02-39$ & 31.50 \\
\hline Gopalpur & Rampur Naikin & K-851 & $24^{0} 17^{\prime} 10.8^{\prime \prime}$ & $81^{0} 20^{\prime} 51.6^{\prime \prime}$ & $07-42$ & 34.25 \\
\hline Madhuri & Sidhi & HUM-1 & $24^{0} 17^{\prime} 23.0^{\prime \prime}$ & $81^{0} 21^{\prime} 28.2^{\prime \prime}$ & $04-42$ & 31.00 \\
\hline Gajaraha & Sidhi & K-851 & $24^{0} 24^{\prime} 25.9^{\prime \prime}$ & $81^{0} 01^{\prime} \quad 13.5^{\prime \prime}$ & $02-28$ & 20.50 \\
\hline Mamder & Rampur Naikin & TM-37 & $24^{0} 24^{\prime} 48.9^{\prime \prime}$ & $81^{0} 33^{\prime} 36.1^{\prime \prime}$ & $03-25$ & 15.60 \\
\hline Mata & Sidhi & HUM-1 & $24^{0} 15^{\prime} 02.9^{\prime \prime}$ & $81^{0} 41^{\prime} 9.6^{\prime \prime}$ & $09-56$ & 47.50 \\
\hline
\end{tabular}


Dubey 2003, proved that seed treatment with Trichoderma viride + Vitavax + Rhizobium is very effective for management of web blight pathogen of mungbean. Tiwari et al., 2002 and Kumar et al., 2017 reported that propiconazole and carbendazim are individually effective against the $R$. solani by maximum inhibiting the mycelial growth and sclerotia formation. Akhtar et al., 2014 found that 0.1 per cent foliar spray of propiconazole at early onset of disease provided 78 per cent reduction in web blight incidence and increases 21.7 per cent in yield over control. Foliar spray of Pongamia glabra leaf extract successfully reduce web blight of urd and mungbean and can be further exploited in organic farming (Dubey, 2002). Sharma and Tripathi, 2001 observed that seed treatment and two foliar sprays of tilt $(0.1 \%)$ at 15 days interval was most effective in reducing disease severity (30$32 \%$ ) and increased grain yield (950-1012 $\mathrm{kg} / \mathrm{ha}$ ) as well as 1000-grain weight followed by bavistin, caftaf and indofil M-45 sprayed plots. Sharma and Tripathi, 2001 reported that propiconazole $(0.1 \%)$ at 15 days interval resulted highest reduction in disease severity $(30-32 \%)$, increases grain yield (950-1012 $\mathrm{kg} / \mathrm{ha}$ ) and 1000-grain weight (35 g).

Table.3 Effect of IDM modules on web blight incidence in mungbean

\begin{tabular}{|c|c|c|c|c|c|c|c|c|}
\hline \multirow[t]{2}{*}{ Treatment } & \multicolumn{4}{|c|}{ Disease incidence $(\%)$} & \multicolumn{4}{|c|}{$\begin{array}{c}\text { Reduction in disease incidence over } \\
\text { check }\left(\mathbf{T}_{1}\right)\end{array}$} \\
\hline & 2016-17 & 2017-18 & 2018-19 & Average & 2016-17 & 2017-18 & 2018-19 & Average \\
\hline $\mathbf{T}_{1}$ & 51.50 & 48.06 & 40.96 & 46.84 & 0.00 & 0.00 & 0.00 & 0.00 \\
\hline $\mathbf{T}_{2}$ & 32.83 & 35.40 & 32.74 & 33.66 & 36.25 & 26.34 & 20.07 & 28.14 \\
\hline $\mathbf{T}_{\mathbf{3}}$ & 14.66 & 15.60 & 18.90 & 16.39 & 71.53 & 67.54 & 53.86 & 65.01 \\
\hline $\mathbf{T}_{4}$ & 8.80 & 9.50 & 9.70 & 9.33 & 82.91 & 80.23 & 76.32 & 80.08 \\
\hline S Em \pm & 1.83 & 1.97 & 2.35 & - & - & - & - & - \\
\hline CD at $5 \%$ & 5.72 & 6.24 & 7.32 & - & - & - & - & - \\
\hline
\end{tabular}

\section{Economics of IDM}

The economics was also calculated after the experimentation based on the expenditure incurred for different IDMs imposed and the income from the yield of mungbean. All the three tested modules were found significantly superior over the control $\mathrm{T}_{1}$ and more return was recorded in tested IDM modules. However, it was observed that maximum average net profit of Rs.12288.25/- per ha was obtained from treatment $\mathrm{T}_{4}$ followed by $\mathrm{T}_{3}$ (Rs. 9016.32/- per ha) which is significantly higher than the usual practice done by the farmers of the area.

The maximum benefit cost ratio of 1.69 was recorded in treatment $\mathrm{T}_{4}$ followed by $\mathrm{T}_{3}$ where $1.52 \mathrm{~B}: \mathrm{C}$ was recorded. The minimum $\mathrm{B}: \mathrm{C}$ of 1.25 was recorded in control $\mathrm{T}_{1}$. The data for economics of different IDM modules are presented in table 5. 
Table.4 Effect of integrated Web Blight management modules on yield and pods per plant in mungbean

\begin{tabular}{|c|c|c|c|c|c|c|c|c|c|c|c|c|c|c|c|c|}
\hline \multirow[t]{2}{*}{ Treatment } & \multicolumn{4}{|c|}{ Yield( kg/ha) } & \multicolumn{4}{|c|}{$\begin{array}{l}\text { Per cent increase in yield over } \\
\text { check }\left(T_{1}\right)\end{array}$} & \multicolumn{4}{|c|}{ Number of pod/ plant } & \multicolumn{4}{|c|}{$\begin{array}{l}\text { Per cent increase in no. of pod/ } \\
\text { plant over check }\left(T_{1}\right)\end{array}$} \\
\hline & $\begin{array}{c}2016- \\
17\end{array}$ & $\begin{array}{c}2017- \\
18\end{array}$ & $\begin{array}{c}2018- \\
19\end{array}$ & Average & $\begin{array}{c}2016- \\
17\end{array}$ & $\begin{array}{c}2017- \\
18\end{array}$ & $\begin{array}{c}2018- \\
19\end{array}$ & Average & $\begin{array}{c}2016- \\
17\end{array}$ & $\begin{array}{c}2017- \\
18\end{array}$ & $\begin{array}{c}2018- \\
19\end{array}$ & Average & $\begin{array}{c}2016- \\
17\end{array}$ & $\begin{array}{c}2017- \\
18\end{array}$ & $\begin{array}{c}2018- \\
19\end{array}$ & Average \\
\hline $\mathbf{T}_{1}$ & 404.00 & 394.25 & 406.00 & 401.42 & 0.00 & 0.00 & 0.00 & 0.00 & 15.20 & 15.00 & 15.40 & 15.20 & 0.00 & 0.00 & 0.00 & 0.00 \\
\hline $\mathbf{T}_{2}$ & 423.75 & 412.50 & 421.50 & 419.25 & 4.89 & 4.63 & 3.82 & 4.44 & 17.00 & 16.80 & 16.20 & 16.67 & 11.84 & 12.00 & 5.20 & 9.67 \\
\hline $\mathbf{T}_{\mathbf{3}}$ & 507.50 & 490.50 & 505.10 & 501.03 & 25.61 & 24.41 & 24.40 & 24.82 & 19.80 & 19.20 & 20.20 & 19.73 & 30.26 & 28.00 & 31.17 & 29.80 \\
\hline $\mathbf{T}_{4}$ & 569.50 & 580.50 & 588.00 & 579.33 & 40.96 & 47.24 & 44.82 & 44.32 & 22.00 & 22.00 & 22.40 & 22.13 & 44.74 & 46.67 & 45.46 & 45.59 \\
\hline S Em \pm & 22.42 & 23.99 & 22.58 & - & - & - & - & - & 0.96 & 0.66 & 0.59 & - & - & - & - & - \\
\hline CD at $5 \%$ & 69.87 & 74.76 & 71.23 & - & - & - & - & - & 3.10 & 2.13 & 1.92 & - & - & - & - & - \\
\hline
\end{tabular}

Table.5 Economic of different IDM modules of web blight management practices in mungbean

\begin{tabular}{|c|c|c|c|c|c|c|c|c|c|c|c|c|c|c|c|c|}
\hline \multirow{2}{*}{$\begin{array}{l}\text { Treat } \\
\text { ment }\end{array}$} & \multicolumn{4}{|c|}{ Cost of Cultivation(Rs./ha) } & \multicolumn{4}{|c|}{ Grass income (Rs./ha) } & \multicolumn{4}{|c|}{ Net income (Rs./ha) } & \multicolumn{4}{|c|}{ B: C ratio } \\
\hline & $2016-17$ & $2017-18$ & $2018-19$ & Average & 2016-17 & $2017-18$ & 2018-19 & Average & 2016-17 & $2017-18$ & $2018-19$ & Average & $\begin{array}{c}2016- \\
17\end{array}$ & $\begin{array}{c}2017- \\
18\end{array}$ & $\begin{array}{c}2018- \\
19\end{array}$ & $\begin{array}{c}\text { Avera } \\
\text { ge }\end{array}$ \\
\hline $\mathbf{T}_{1}$ & 16137.25 & 16212.50 & 16230.25 & 16193.33 & 19448.00 & 20501.00 & 21112.00 & 20353.67 & 3310.75 & 4288.50 & 4881.25 & 4160.17 & 1.20 & 1.26 & 1.30 & 1.25 \\
\hline $\mathbf{T}_{2}$ & 16205.00 & 16345.50 & 16412.25 & 16320.92 & 26364.00 & 21450.00 & 21918.00 & 23244.00 & 5830.00 & 5104.50 & 5505.95 & 5480.15 & 1.35 & 1.31 & 1.33 & 1.33 \\
\hline $\mathbf{T}_{\mathbf{3}}$ & 16895.75 & 16990.00 & 17096.50 & 16994.08 & 26260.00 & 25506.00 & 26265.20 & 26010.40 & 9364.25 & 8516.00 & 9168.70 & 9016.32 & 1.54 & 1.50 & 1.53 & 1.52 \\
\hline $\mathbf{T}_{4}$ & 17720.75 & 17842.00 & 17948.50 & 17837.08 & 29614.00 & 30186.00 & 30576.00 & 30125.33 & 11893.25 & 12344.00 & 12627.50 & 12288.25 & 1.67 & 1.69 & 1.70 & 1.69 \\
\hline
\end{tabular}


The present study incorporating chemical, bio-control agent, with compost and phytoextract use in an integrated manner can be successfully utilized not only in web blight management but also in increased yield and benefit cost ratio in mungbean.

\section{Acknowledgement}

The author acknowledges the help and technical support of Ashish Kumar in preparing this manuscript.

\section{References}

Akhtar, J., Lal, H.C., Kumar, Y., Singh, P.K., Ghosh, J. and Khan, Z. 2014. Multiple disease resistant in Greengram and Blackgram germplasm and management through chemicals under rain-fed conditions. Legume Res. 37: 101-109.

Anonymous 2014. Project Cordinator's Report ( Mungbean and Urd bean). All India Co-ordinated Research Project on MULLaRP, Indian Institute of Pulse Research, Kanpur, 2013-14.

Anonymous.2017. Annual Report 2016-17, Directorate of Pulses Development, Govt. of India, Ministry of Agriculture and Farmers Welfare, Bhopal (DPD/ Pub/TR/19/ 2016-17), 13pp.

Bains, S.S., Dhaliwal, H.S. and Basandrai, A.K. 1988. A new blight of Mung and Mash in Punjab. Ann. Biol. Ludhiana. 4: 113-114.

Chauhan, Y.S., Douglas, C., Rachaputi, R.C.N., Agius, P., Martin, W., King, K., et al., 2010. Physiology of mungbean and development of the mungbean crop model," in Proceedings of the 1st Australian Summer Grains Conference Australia, Gold Coast, QL. 21-24.

Dubey, S.C. 2002. Efficacy of some oil cakes and plant extracts against web blight of urd and Mungbean caused by Thanatephorus cucumeris. J. Mycol. Pl.
Pathol. 32: 158-61.

Dubey, S.C. 2003. Integrated management of web blight of Urd/Mungbean by bioseed treatment. Indian Phytopath. 56(1): 34-38.

Dubey, S.C. and Patel, B. 2002. Mass multiplication of antagonists and standardization of effective dose for management of web blight of Urd and Mungbean. Indian Phytopath. 55: 338341.

Dubey, S.C., Bhavani, R. and Singh, B. 2011. Integration of soil application and seed treatment formulations of Trichoderma species for management of wet root rot of Mungbean caused by Rhizoctonia solani. Pest Manag. Sci. 67:1163-1168.

Dwivedi, R.P. and Saksena, H.K. 1974. Occurrence of web blight caused by Thanatephorus cucumeris on Mungbean. Indian J. Farm Sci. 2: 100.

Gupta, R.P., Singh, S.K. and Singh R.V. 2010. Assessment of losses due to web blight and weather effects on disease development in Mungbean. Indian Phytopath. 63(1):108-109.

Itoh, T., Garcia, R.N., Adachi, M., Maruyama, Y., Tecson-Mendoza, E.M., Mikami, B., et al., (2006). Structure of $8 \mathrm{~S} \alpha$ globulin, the major seed storage protein of mungbean. Acta Crystallogr. D. Biol. Crystallogr. 62: 824-832.

Jain, A.K., Kumar, A., Chouhan, S.S. and Tripathi, S.K. 2016. Cultural characteristics and evaluation of Trichoderma isolates against Rhizoctonia solani Kuhn causing banded leaf and sheath blight of little millet. Annals of Plant Protection Sciences. 25(1):140-143

Jhamaria, S.L. and Sharma, O.P. 2002. Management of web blight of mungbean through chemicals and plant product. Indian Phytopath. 55: 526.

Kumar, A., Govil, M., Singh, S., Sharma, K.K., Tripathi, S.K., Tiwari, R.K., 
Tripathi, A.N. and Singh, S. 2015. Role of Micro-organisms in Bioremediation: A Comprehensive Model Using Trichoderma spp. Handbook of research on uncovering new methods for ecosystem management through bioremediation. doi:10.4018/978-14666-8682-3.ch002

Kumar, A., Kumar, S., Srivastava, R. and Sharma, A.K. 2009. Fungal biocontrol agents (BCAS) and their metabolites. In. Agricultural Diversification: Problems and Prospects (Eds. by A.K. Sharma, S. Wahab and R. Srivastava). I. K. International, New Delhi, pp.44-56.

Kumar, A., Sahu, T.K., Bhalla, A. and Jain, A.K. 2014. Morphological characterization of Trichoderma harzianum from Madhya Pradesh. Annals of Plant Protection Sciences 22(1): 228-229.

Kumar, V., Chaudhary, V.P., Kumar, D., Kumar, A., Sagar, S. and Chaudhary, S. 2017. Efficacy of botanicals and fungicides against Rhizoctonia solani inciting sheath blight disease on Rice (Oryza sativa L.). J. Appl. Nat. Sci. 9(4): 1916-1920.

Nacien, C.C. 1924. Studies on Rhizoctonia blight of beans. Philippine Agriculturist 8: 315-321.

Nene, Y.L. 1972. A survey of viral diseases of pulse crops in Uttar Pradesh. Final Tech. Report. Res. Bull. No. 4, U.P. Agricultural University, Pantnagar, India, pp. 1-91.

Pratap, A., Gupta, S., Basu, S., Tomar, R., Dubey, S., Rathore, M., et al., 2019.
Towards Development of ClimateSmart Mungbean: Challenges and Opportunities," in Genomic Designing of Climate Smart Pulse Crops. Ed. Kole, C. (New York: Springer Nature).

Saikia, U.N. 1976. Blight of mung caused by Corticium sasakii a new disease recorded from Assam. Indian Phytopath. 29: 61-62.

Sharma, J. and Tripathi, H.S. 2001. Biological and chemical control of web blight disease of urdbean. Indian Phytopatho. 54(2): 267-269.

Singh, J., Singh, R.B. and Singh, S.K., 2003. Status of web blight of Mungbean in Eastern Uttar Pradesh. Annals of Pl. Prot. Sci. 11(1):173-175.

Singh,J. Singh, R.B. and Balai, L.P. 2012. Grain Yield Loss in Mungbean due to Web Blight Trends in Biosciences 5(2):147-148.

Srivastava, R., Joshi, M., Kumar, A., Pachauri, S. and Sharma, A.K. 2009. Biofertilizers for sustainable agriculture. In Agricultural Diversification: Problems and Prospects (Eds. By A.K. Sharma, S. Wahab and R. Srivastava). I.K. International, New Delhi, pp. 57-71.

Tiwari, A. and Khare, M.N. 1998. Variability among isolates of Rhizoctonia solani infecting mungbean. Indian Phytopath. 51: 334-337.

Tiwari, R.K.S., Chandravanshi, S.S., Ojha, B.M. and Thakur, B.S. 2002. In vitro and In vivo efficacy of new fungicides against $R$. solani causing sheath blight disease of rice. J. Mycol. Pl. Pathol. 32(3): 418.

\section{How to cite this article:}

Jai Singh, Ashish Kumar and Sharma. S. R. 2020. Efficacy of Integrated Management of Web Blight of Mungbean in Kymore Plateu and Satpura Hills Agroclimatic Zone of Madhya Pradesh, India. Int.J.Curr.Microbiol.App.Sci. 9(03): 450-458. doi: https://doi.org/10.20546/ijcmas.2020.903.052 